\title{
The Implementation of Multicultural Value of Pela Gandong Local Wisdom in Education
}

\author{
Anju Nofarof Hasudungan* and Lianda Dewi Sartika** \\ Department of History Education, Sebelas Maret University, Surakarta, Indonesia
}

\begin{abstract}
Collective memory of the Ambon Maluku community towards the conflict occurred in 1999-2003 that has awakened the value of pela gandong local wisdom owned for hundreds of years is very important to maintain. The function is also optimized to maintain the reconciliation of the Ambon Maluku conflict that has been achieved. The Ambon Maluku community defines pela gandong as the friendship model, fraternity system, or alliance system that was developed among all indigenous people from two or more countries even before the colonial arrived. When the Ambon conflict occurred, pela gandong became part of the conflict resolution. At present, the Ambon Maluku community has expanded the function of pela gandong to various fields including education. This study aimed to reveal the implementation of the value of pela gandong local wisdom in education and becoming a model of multicultural education in Maluku. This study was conducted in January 2018 at SMPN 9 Ambon with 99\% of Christian/Catholic students and SMPN 4 Salahutu Liang with $100 \%$ of Moslem students. The research method used was descriptive qualitative to obtain the answers of the research. The data collecting techniques were literature study, interview, and participatory observation. The results of the research showed that the implementation of the values of pela gandong was relevant and could be integrated as a model of multicultural education.
\end{abstract}

Keywords: Local Wisdom, Multicultural Value, Pela gandong, Ambon Conflict Reconciliation

\section{Introduction}

Achieving the reconciliation of the Ambon Maluku conflict in 2002 was inseparable from the local wisdom of the Ambon community, pela gandong, which was able to become part of the conflict resolution. This occurred due to the collective memory of the Ambon Maluku community to end the biggest civil conflict in Indonesia as soon as possible. The effort produced the result by returning the function and purpose of pela gandong local wisdom in the period before the conflict occurred, namely the fraternity bond without distinguishing religion. In this case, it could be found out that the local wisdom of the community could naturally maintain stability and harmonization of the community's life. Political and military forces of the new order to maintain security stability and harmonization of the community were only pseudo. The proof was that after the new order ended, the occurrence of many social/religious conflicts was just like the iceberg phenomenon. According to Aditjondro (2001), during the new order was in power, it had made religion and ethnicity as a propaganda mechanism.

The reconciliation of the Ambon Maluku conflict through the Malino II Agreement on February 12, 2002, became the new beginning for the Ambon Maluku community to live in peace. The next responsibility after the reconciliation achieved was to maintain peace and actualized by expanding the function and purpose of pela gandong to the fields which had not been touched before and during the conflict, including the field of education. At present, pela gandong transforms into the field of education, touching the young generations who did not experience the Ambon Maluku conflict of 1999-2003. This is carried out considering that the Ambon Maluku conflict in addition to causing hundreds of thousands of fatalities also severed the inter-religious harmony, the personality changes between individuals and groups, the economic wheel failure and the polarization of the population in the Ambon Maluku community to this day. 
Ohorella (1999) in Brauchler (2009) stated that pela has to be adjusted with the modern condition. To cover all the Maluku communities, the pela gandong system has to be expanded to integrate more villages and has to be moved to the higher level to create pact between regencies so that it automatically integrates all villages in Maluku. In this way, Ohorella expected that the pela gandong values of fraternity and helping each other in the crisis can be transferred to all aspects of the Maluku community: social, culture, education, religion, economy, politics, government, and security sector.

What was thought by M. G. Ohorella in 1999 finally began to produce the result by expanding the function and purpose of pela gandong to the fields which had not been touched before and during the conflict, including the field of education? At present, pela gandong transmits in the field of education, touching the young generations who did not experience the Ambon Maluku conflict of 1999-2003. In the term of the United Nations (UN) and the United Nations Children's Fund (UNICEF), it becomes the Project of Peace Education. This is carried out considering that the Ambon Maluku conflict in addition to causing hundreds of thousands of fatalities also severed the inter-religious harmony, the personality changes between individuals and groups, the economic wheel failure and the polarization of the population in the Ambon Maluku community to this day. The turmoil of Ambon resulted in thousands of deaths and tens of thousands of injuries. An estimated one-third to half of the population was displaced, and countless traits were flattened (see International Crisis Group (ICG) 2000a, 2000b, 2002, 2004 in Qurtuby, (2013)).

The conflict did not only affect on groups but also individuals. Therefore, the mainstreaming of Peace Education is needed to keep maintaining the peace reconciliation that will be inherited to the next generation. Do not let the stories of Ronald Regang (the 10-year-old Former Combatant of the Christian Forces) and Iskandar Slameth (the 15-year-old Islamic Jihad Forces) aired on August 16, 2018, on the Rosi program on the Kompas TV station of the independence episode of "Learning Peace from Maluku" reoccur.

The research of the dissertation of Alpha Amirrachman (2016) entitling Peace Education in the Moluccas, Indonesia: Between Global Models and Local Interests had begun the project of Peace Education at several schools in Ambon City in 2006 and pioneered by international institutions like UNDP (United Nations Development Program) dan UNICEF (United Nations Children's Fund) rushed to the province to introduce the peace education, then followed by JICA (Japan International Cooperation Agency). The project of Peace Education was claimed to include the elements of the local tradition of Central Maluku to help to decrease violence. On the other hand, when the project of the peace education was begun by UNICEF cooperating with the Provincial Office of North Maluku after the conflict, North Maluku had implemented the locally based curriculum that had been recorded. It was not socialized in the implementation of education to both teachers, students, and the local community so that the results of the formula could not be implemented (Sapsuha, 2013). Then, how was the implementation of the multicultural value of pela gandong local wisdom after the reconciliation of the Ambon conflict at SMPN 9 Ambon City and SMPN 4 Salahutu Liang Central Maluku? Did it work well? In the pre-observation on January 25-30, 2018, the author found out that the schools that were previously in the conflict were able to reconcile and even establish the fraternity bond based on pela gandong local wisdom.

The dissertation of Steve Gerardo Christoffel Gaspersz (2016): the abstract of the dissertation of Gadjah Mada University entitling Negotiating Religious Identities, Cultural Authorities and Modernity in Leihitu, Ambon Island described that the development strategy of the local community in the broad and fundamental definition can be implemented by understanding the worldview of the local community as a manifestation of historical and cultural awareness which is formed through the long and dynamic life experience. Gaspersz (2016) also added that at that point, this study offered a new perspective regarding the cultural strategy for the community development with the orientation of finding the intrinsic values from the local tradition as a foundation to absorb the social changes which are in line with the local wisdom which is their social and cultural model. The findings of this research were certainly only an open model to be continuously tested in the changing sociopolitical and 
cultural context. Furthermore, Gaspersz (2016) suggested that further researches have to move forward to find and reconstruct the development models which favor the future and the better Indonesian "global" community life. Gaspersz (2016) also explained that the model of international and local peace education will certainly be different.

Therefore, the main purpose of the initiative of the community at SMPN 9 Ambon City and SMPN 4 Salahutu Liang Central Maluku to begin the new era by implementing the multicultural values of pela gandong local wisdom in schools. It is intended that students in the two schools with different religious embraces can learn to live a tolerant life through a local wisdom approach. No more hate and inner wounds due to the conflict.

\section{Research Method}

This study used the descriptive qualitative research methodology with the case study approach. A case study includes a study of a case in the real life, in the context or contemporary setting (Yin, 2009 in Creswell, 2018:135). The data collecting techniques used were observation-participation, literature review, interview, and documentation.

The research respondents included related parties with a total of ten speakers consisting of one school principal, two Social Studies Subjects teachers, and three students at SMPN 9 Ambon City. While at SMPN 4 Salahutu Liang with the resource person of one school principal, one Social Studies subject teacher, two students, and the governor of Maluku at the time.

The collected data in this research were words description, actions and documents, situations and events that could be observed (Bachri, 2010: 50)). The intended data sources were:

Table 1:Data souce of pela gandong research method

\begin{tabular}{l|l}
\hline Data Type & Data Collection Technique \\
\hline The words desciption & Directly or indirectly obtained through interview and observation. \\
\hline The documents & The curriculum, Learning Unit, and Lesson Plan. \\
\hline The situations & $\begin{array}{l}\text { Related to the activities of the research subjects and the research problems, } \\
\text { such as in the teaching and learning process, the learning situation in the } \\
\text { library, and the situation in the school environment. }\end{array}$ \\
\hline
\end{tabular}

\section{Results and Discussion}

\section{Multicultural Education with Local Wisdom Approach}

The implementation of the education system stated in Law number 20 of 2003 concerning the National Education System of the Chapter III of the Education Implementation article 4 paragraph (1) stated that the Education is organized democratically and justly as well as in a non-discriminatory manner by upholding human rights, religious values, cultural values and national pluralism. It means that the implementation of the education system has to adopt a multicultural spirit rooted in the local wisdom values. The multicultural education based on the local wisdom is an education that protects, appreciates, and maintains the local wisdom to strengthen the national identity in the frame of national pluralism. As Pancasila which is explored from the national personality, the motto of Bhinneka Tunggal Ika becomes the historical basis that the Indonesian nation is a multicultural nation.

The reason behind the existence of multicultural education is the existence of a community consisting of individuals with diverse backgrounds of language and nationality, race or ethnicity, religion, gender, and social 
class. The diversity of backgrounds of individuals in a community has an implication on the diversity of backgrounds of students in an educational institution (Banks, 1997).

\section{Multicultural Value of Pela gandong}

The Maluku community defines pela as a friendship model or fraternity system, or an alliance system developed between all indigenous people from two or more countries. The system bond has been established by the ancestors in specific circumstances with certain rights and obligations agreed upon. Pela is a fraternity bond or relationship between all people from two or more villages based on the tradition.

"Pela as it is found a present in Moluccan societies, is an institutionalized bond of friendship or brotherhood between all native residents of two or more villages, which bond was established by the ancestors." (Colley, 1961)

On the other hand, there is also another opinion stating that pela is an alliance or friendship system between several villages or countries.
"The keystone among several centerpieces is an intervillage alliance system called Pela. Pela as it exists in Ambon today, is a system of relationship tying together two or more villages, often of apart and frequently on different island." (Bartels, 1977)
Furthermore, Bartles (1977) conveyed that pela is an agreement on a social system that occurs without considering other aspects. The most important thing is the fraternity that has been bound. The above definitions position pela on the highest and most respectable social structure beyond the biological sibling relations. The first time pela gandong revived in a revitalizing effort was presented in the arumbai mangurrebe competition (a form of traditional boat race), which was revived in 2005 (Brauchler, 2009).

Table 2:Multicultural values of pela gandong.

\begin{tabular}{ll}
\hline No. & Multicultural values of pela gandong \\
\hline 1. & $\begin{array}{l}\text { Concepts; hidup orang Basudara, Potong di kuku rasa di daging, Ale Rasa Beta Rasa, Sagu } \\
\text { Salempeng di pata dua, Ain ne ain, Kalwedo, Kidabela, Sitakaka walike and others are the } \\
\text { local contents packaged in the tradition of the harmonization of the Basudara people in } \\
\text { Maluku. }\end{array}$ \\
\hline $2 . \quad \begin{array}{l}\text { Pela and gandong have become the developing social institutions as an adhesive on the } \\
\text { social relations between one village and another, both Moslem and Christian. }\end{array}$ \\
\hline 3. $\quad \begin{array}{l}\text { Pela and gandong are very functioning in regulating the system of the social interaction of } \\
\text { the custom society that transcends various fields. }\end{array}$ \\
\hline 4. $\quad \begin{array}{l}\text { Pela gandong is a friendship model or fraternity system, or an alliance system that is } \\
\text { developed between all the indigenous people from two or more countries. The system bond } \\
\text { has been established by the ancestors in specific circumstances with certain rights and } \\
\text { obligations agreed upon. }\end{array}$ \\
\hline
\end{tabular}

The interesting thing to note is that after the Maluku conflict in 1999-2003, there were so many Maluku regional songs that portrayed the values of the fraternity life among the Moluccan people whom were portrayed from the relationship between pela and gandong. The concepts; hidup orang Basudara, Potong di kuku rasa di daging, Ale Rasa Beta Rasa, Sagu Salempeng di pata dua, Ain ne ain, Kalwedo, Kidabela, Sitakaka walike and others are the local contents packaged in the tradition of the harmonization of the Basudara people in Maluku.

Pela and gandong have become the developing social institutions as an adhesive on the social relations between one country and another, both Moslem and Christian. Therefore, pela and gandong are very functioning in regulating the system of the social interaction of the custom society that transcends various fields. Dieter Bartles, an American anthropologist researched pela in Maluku and defined pela as a friendship model or fraternity system, or an alliance system that is developed between all the indigenous people from two or more 
countries. The system bond has been established by the ancestors in specific circumstances with certain rights and obligations agreed upon. Bartles viewed pela as an agreement on a social system that occurs without considering other aspects. The most important thing is the fraternity that has been bound. The above definitions position pela on the highest and most respectable social structure beyond the biological sibling relations.

The current trends in Maluku are in line with the broader developments on an international scale, in which truth commission and law enforcement, justice and human rights, remission and amnesty often fail as a means of reconciliation. According to Brauchler (2009), this causes two trends around the world where the Maluku case is very suitable: (1) the ordinary people affected by mass cruelties increasingly mobilize the traditional institutions or conflict resolution mechanisms for peace and stability to compensate for inadequacy or national failure and international intervention; and (2) the people and organizations involved in the development of the conflict resolution strategies have begun to think about the integration of the cultural factors into the reconciliation process.

Lederach (1997) stated that "the greatest resource to maintain peace in the long term is always rooted on the local people and their culture." The research on the peaceful culture based on the pela tradition also showed that the pela gandong tradition contains more dimensions of collectivism than individualism (Hofstede \& Hofstede, 2005).

The Implementation of the Multicultural Value of Pela gandong at SMPN 9 Ambon City and SMPN 4 Salahutu Liang Central Maluku

Multicultural education is a concept or idea as a set of belief and explanation that acknowledges and assesses the importance of the cultural and ethnic diversity in forming the lifestyle, social experiences, personal identity, and educational opportunities from individuals, groups, or country (Banks, 2001). It can be seen from 3 (three) aspects: concept, movement, and process (Banks, 1997). From the aspect of concept, multicultural education is understood as an idea that views all students — without considering their gender and social class, their ethnicity, their race, and or other cultural characteristics - to have the equal opportunities to study in the classroom. From the aspect of movement, multicultural education is defined as an effort to change schools and educational institutions so that the students coming from all social classes, genders, races, and cultural groups have the equal opportunities to study.

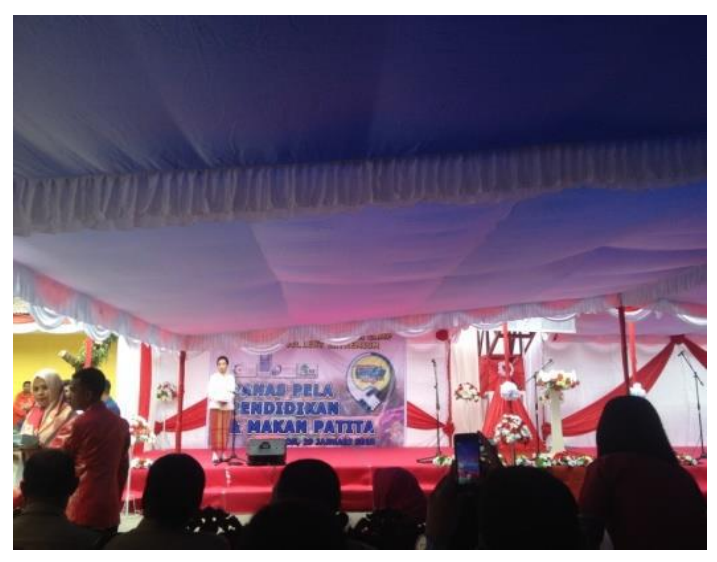

Figure 1:The event of education panas pela at SMPN 9 Ambon City and SMPN 4 Salahutu Liang Central Maluku on January 29, 2018.

In the context of this topic, pela gandong became the source of the multicultural value at SMPN 9 Ambon City and SMPN 4 Salahutu Liang Central Maluku. Multicultural education is taught through the learning process in the classroom, the habituation, the spontaneity, the environmental conditioning, and the exemplary. The 
habituation and exemplary are carried out in the school environment by involving all the school people. The learning process of multicultural education is carried out by the teacher of Guidance and Counseling $(B P)$ whom is responsible for the implementation of the process of multicultural education starting from the plan, implementation, and evaluation. However, all the school people are required to support multicultural education through the habituation and exemplary that are implemented in various routines and activities of instilling multicultural values to the students (Pelu, 2017).

Table 3:The implementation of the multicultural values of pela gandong.

No. The implementation of the multicultural values of pela gandong at SMPN 9 Ambon City and SMPN 4 Salahutu Liang Central Maluku

1. The transformation of the pela values keeps being carried out. One of them is the promotion of the pela education as well as the education at SMPN 9 Ambon City where 99 percent of the students and teachers are Christian and at SMPN 4 Salahutu Liang Central Maluku where 100 percent of the students and teachers are Moslem.

2. Teacher exchanges between SMPN 9 Ambon City and SMPN 4 Salahutu Liang are conducted four times a year, at the beginning and end of each semester. So the Christian religion teacher from SMPN 9 Ambon City came to SMPN 4 Salahutu Liang to learn about Islam and vice versa. Islamic religion teacher from SMPN 4 Salahutu Liang came to SMPN 9 Ambon City to learn about Christianity. It is intended that both adherents of different religions can understand each other's religions so that differences do not make the two adherents hate each other, but rather tolerance will arise and harmony will be created in these differences.

3. The good relationship between students and teachers in both schools are harmonious and getting along better. Almost every year, the two schools carry out 'reunions' called Panas Pela in the traditional term. Panas pela was marked by eating betel nut by the Headmaster of SMPN 9, Ambon E. Harmusial accompanied by the Chairman of the Student Council, Jack Dea together with the Headmaster of SMPN 4 Salahutu, Hilia Pary and the Chairman of the Student Council, Dimara Dinasti Laga.

4. Besides Panas Pela, they often make joint activities for the students, such as the week of sport and art (Porseni) competitions, scouts, breaking the fast together, celebrating Christmas together, joint student council activities.

5. The two schools were also part of the filmmaking of the 2013 Peaceful Provocateur as a form of peace campaign and the value of multicultural diversity.

In an interview to Ambon DMS Radio and N25news.Com, the Maluku Governor who was present at that time, Said Assagaf said:

\begin{abstract}
"It cannot be denied that the development of an increasingly modern era often brings tendencies and forgets the cultural values, regional customs that have been inherited from our ancestors for a long time. Pela culture is one of the social systems that is a social bond of two countries or a pledge of promise bound by our ancestors to maintain the fraternity with one another. The existence of panas pela education from these two schools will become an example to be imitated by other schools and educational institutions in order to improve the relationship of tolerance and implement it in the culture. Panas pela education is expected to provide the positive value on the quality education for our students at these two institutions."
\end{abstract}

The implementation of the multicultural value of pela gandong at SMPN 9 Ambon City and SMPN 4 Salahutu Liang Central Maluku is carried out in the learning process in the classroom, the habituation, the spontaneity, the environmental conditioning, and the exemplary.

In line with this research, the results of research from R. Alpha Amirrachman's (2016) dissertation entitled Peace Education in the Moluccas, Indonesia: Between Global Models and Local Interests, regarding peace education in Maluku between the interests of global and local models has begun the Peace Education Project (Peace Education) in several schools in the city of Ambon in 2006 spearheaded by international institutions such as UNDP (United Nations Development Program) and UNICEF (United Nations Children's Fund) rushed to the 
provinces to introduce peace education, then followed by JICA (Japan International Cooperation Agency. The peace education project is claimed to include elements of the Central Maluku local tradition to help reduce violence.

Then in his writing in the Journal of South East Asia Research Vol. 22, No. 4, Special Issue: Education For A Tolerant And Multicultural Indonesia (December 2014), pp. 561-578 titled Education in the conflict-affected Moluccas: Local tradition, identity politics, and school principal leadership, found that suspicion and hatred between Muslim and Christian students remained intact in Schools 1,2 and 3, although they received educational intervention peace. In these schools, peace education projects are framed in what is considered a local Maluku tradition. However, School 4 was able to reduce the impact of conflict and maintain peace in the school, although the school did not receive specifically designed peace education interventions. School 4 students show a strong preference for national identity, which includes religious and ethnic boundaries. This study shows that identity politics is playing in the form of inclusion of what is considered a local Maluku tradition but other possible exceptions in the peace education curriculum, as the case of Schools 1, 2 and 3 shows. This study also shows that the principal's leadership is very prominent in helping to create a peaceful atmosphere, as the case of School 4 revealed.

Furthermore, in Al Qurtuby's study, 2013 entitled Peacebuilding in Indonesia: Christian-Muslim Alliances in Ambon Island. Kroc Institute for International Peace Studies, University of Notre Dame, Indiana, USA. Local wisdom (pela gandong) has proven to be part of the Ambon conflict resolution.

\section{The Multicultural Value of Pela gandong as a Model of Multicultural Education of Millennial Era}

Millennial era education is marked by the writing of the $21^{\text {st }}$ century abilities. The important skills in the $21^{\text {st }}$ century are still relevant to the four pillars of life of United Nations Educational, Scientific and Cultural Organization (UNESCO) which consist of learning to know, learning to do, learning to be and learning to live together. (http://www.unesco.org/new/fr/education/networks/globalnetworks/aspnet/about-us/ strategy/the-fourpillars-of-learning/).

Learning to live together, this fourth pillar is relevant to the multicultural values of pela gandong. Learning to live together consists of habit of living together, mutual respect, openness, giving and receiving needs to be developed in schools. This kind of condition allows the growth of mutual understanding among race, ethnicity, and religion. With the ability possessed, as a result of the educational process, it can be used as a provision to be able to play a role in the environment where the individual is, and place themselves in accordance with their role. An understanding of the self-role and others in the learning group is a provision in socializing in the community (learning to live together). Thus, the multicultural values of pela gandong can become an adhesive for learning to live together in schools.

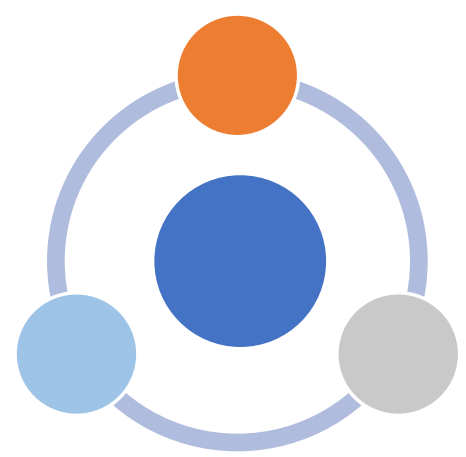

Figure 2. The framework of thinking of the implementation of the multicultural value of pela at SMPN 9 Ambon City and SMPN 4 Salahutu Liang Central Maluku. 
Pela gandong local wisdom turns out to have multicultural values contained therein. The existence of these multicultural values is a distinct advantage for SMPN 9 Ambon City and SMPN 4 Salahutu Liang as a millennial era multicultural education model.

\section{Conclusion}

The form of multicultural education in Pela gandong is that, with various cultural attractions displayed by students of both schools through dance, song, and poetry, all of which lead and invite students to live with one another to love each other despite different ethnic and group religions. Pela's relationship between the two schools has been established several years ago by carrying out some joint activities including, sports and arts week competitions, Scouting, breaking fast together, Christmas together, student council activities together to exchange teachers teaching the two schools. Thus, multicultural education in Pela gandong has been able to become a multicultural model of education in the millennial era after the Ambon conflict reconciliation.

\section{References}

Aditjondro, G. J. (2001). Ketika Semerbak Cengkih Tergusur Asap Mesiu, Tragedi Kemanusiaan Maluku di Balik Konspirasi Militer, Kapitalis Birokrat, dan Kepentingan Elit Politik. Sekretariat Tapak Ambon: Jakarta.

Amirrachman, A. (2016). Peace Education in the Moluccas, Indonesia: Between Global Models and Local Interests. ISBN. 9789792579130. Faculty of Social and Behavioral Sciences (FMG) Amsterdam Institute for Social Science Research (AISSR).

Banks, J. A., \& McGee Banks, C. A. (Eds.). (1997). Multicultural education: Issues and Perspectives (3rd ed). Boston: Allyn and Bacon.

Bank, J. A. \& Mc.Gee, C. A. (2001). Handbook of Research on Multicultural Education. Jossey Bass: San Fransisco.

Bartels, D. (1977). Guarding the Invisible Mountain: Alliances, Religious Syncretism and among the Ambonese Christian and Moslems in the Moluccas. Phd Thesis. Cornel University.

Bachri, B. S. (2010). Meyakinkan Validitas Data Melalui Triangulasi Pada Penelitian Kualitatif. Teknologi Pendidikan, 10, 46-62.

Bräuchler, B. (2009). Cultural solutions to religious conflicts? the revival of tradition in the Moluccas, Eastern Indonesia. Asian Journal of Social Science 37, 872 - 891. DOI: 10.1163/156848409X12526657425226.

Cooley. (1961). Althar and Throne in Central Moluccas Societies. Phd Thesis. Yale University.

Creswell, J. W. (2018). Penelitian Kualitatif dan Desain Riset Memilih di antara Lima Pendekatan (Edisi ke-3). Pustaka Pelajar: Yogyakarta.

Gaspersz, S. G. C. (2016). Negotiating Religious Identities, Cultural Authorities and Modernity in Leihitu, Ambon Island. Dissertation.

Hofstede, G. \& Hofstede, G. J. (2005). Culture and Organizations Software of the Mind. McGraw-Hill.

LAW OF THE REPUBLIC OF INDONESIA, Number 20 of 2013, National Education System.

Lederach, J. P. (1999). Building Peace: Sustainable Reconciliation in Divided Societies. Library of British Council: Liverpool.

Moleong, L. J. (2007). Metodologi Penelitian Kualitatif. PT Remaja Rosdakarya Offset: Bandung.

Nasution. (2003). Metode Research. PT. Bumi Aksara: Jakarta.

Pelu, M. (2017). Pendidikan Budi Pekerti di Sekolah Pemberdayaan Modal Sosial dan Modal Budaya. UNS Press: Surakarta.

Qurtuby, S. A. (2013). Peace Building in Indonesia: Christian-Muslim Alliances in Ambon Island. Kroc Institute for International Peace Studies: University of Notre Dame, Indiana, USA. 
Anju Nofarof Hasudungan and Lianda Dewi Sartika /The Implementation of...

Sapsuha, M. T. (2013). Pendidikan Pascakonflik Pendidikan Multikultural Berbasis Konseling Budaya Masyarakat Maluku Utara. LKIS: Yogyakarta.

http://www.unesco.org/new/fr/education/networks/global-networks/aspnet/about-us/strategy/the-four-pillars-oflearning/, Date of access: 5/7/2018. 